\title{
Research on Development of the Practical Teaching of Ideological and Political Theory Courses in Colleges and Universities Since the Reform and Opening Up
}

\author{
Lin Yi*, Jiang Lili \\ The School of Marxism, Tiangong University, Tianjin, P. R. China \\ Email address: \\ yilin161103@126.com (Lin Yi), 997938252@qq.com (Jiang Lili) \\ ${ }^{*}$ Corresponding author
}

To cite this article:

Lin Yi, Jiang Lili. Research on Development of the Practical Teaching of Ideological and Political Theory Courses in Colleges and Universities Since the Reform and Opening Up. Humanities and Social Sciences. Vol. 7, No. 6, 2019, pp. 202-208.

doi: $10.11648 /$ j.hss. 20190706.13

Received: November 1, 2019; Accepted: November 29, 2019; Published: December 6, 2019

\begin{abstract}
Since the Reform and Opening Up, our party and country attach great importance to the construction of Ideological and political theory courses in Colleges and universities, especially the setting of practical practice teaching part. As an extension part of the theoretical teaching of Ideological and political courses in Colleges and universities, it has played an important role in promoting the effectiveness of Ideological and political education in Colleges and universities and enhancing the sense of acquisition of College Students' Marxist theory learning. Reviewing the development of the practical teaching of Ideological and political theory course in Colleges and universities since the reform and opening up, strengthening the understanding of the connotation of the practical teaching of Ideological and political course in Colleges and universities, so as to better grasp the present situation of its development and Reform. It is of great theoretical and practical significance to guide the practical work and improve the quality of Ideological and political education in Colleges and universities.
\end{abstract}

Keywords: Reform and Opening Up, Ideological and Political Theory Courses, Practical Teaching

\section{Introduction}

General Secretary Xi Jinping delivered an important speech at the forum of teachers of Ideological and political theory held in March 18, 2019. He stressed the need to build up the spirit of socialism with Chinese characteristics and implement the party's educational policy and implement the basic task of Strengthing Morality. He said that we should pay attention to reform and innovation to run the Ideological and political theory course well in the new era, and constantly enhance the ideological, theoretical, affinity and pertinence of the Ideological and political course. For this reason, he put forward the requirements of "Eight Unifications", in particular, we should "adhere to the unity of theoretical and practical nature, educate people with scientific theory, attach importance to the practicality of the Ideological and political course, and make the small Ideological and political class the big social class together with the classroom, guide students to set up their lofty ideals and become the strivers. At present, the national colleges and universities generally increase the corresponding practical teaching hours in the Ideological and political courses, and the practical teaching designs have various forms. The practice teaching of Ideological and political theory course in Colleges and Universities has become an important part. It not only becomes the highlight of Ideological and political course teaching in various schools in form, but also can echo and complement each other in content. Not only it has made ideological and political education more flexible and grounded, but been welcomed by both teachers and students, and effectively improved the reality of ideological and political course effectiveness.

\section{The Conception of Practical Teaching of Ideological and Political Theory Course in Colleges and Universities}

At present, there have been many researches on the 
conception of the practical teaching of ideological and political courses in colleges and universities. For example, Professor Zhang Guofu in "the Discussion on the Practical Teaching of Ideological and Political Theory Courses in Colleges and Universities" has taken a point as that, "the practical teaching of ideological and political theory courses is based on the syllabus, with various forms of activities as the carrier, with stable practice base as the support, education and contribution as the goal, and education practice activities with understanding society and serving society as the main content." [1] The Scholar Chen liming in his research on "the Reflections on the Practical Teaching of Ideological and Political Theory Course in Colleges and Universities" said that, "the practical teaching of ideological and political theory course refers to the teaching activities that are related to the content of the course, in addition to the classroom theoretical teaching, and that emphasizes the active participation of students and the leadership of teachers". [2]

By analyzing and combing the previous views, combined with the practical teaching experience, the author thinks that we should understand and grasp the connotation of the practical teaching of ideological and political courses in Colleges and universities from the following aspects.

\subsection{Based On the Theory of Ideological and Political Courses}

As an effective extension of ideological and political courses in Colleges and universities, practical teaching bears the same social responsibility as the normal teaching of ideological and political courses, both in form and content. As General Secretary Xi Jinping had said at the end of 2016 at the National Conference held on Ideological and Political Work in Colleges and Universities, "it is clear that, ideological and political work in Colleges and universities is related to the fundamental problem of what kind of people colleges and universities cultivate, how to cultivate people and for whom". Our national colleges and universities are under the leadership of the Communist Party of China and the Socialist Colleges and universities with Chinese characteristics. Therefore, we should do a good job in the ideological and political theory course and design the practical teaching of Ideological and political course in Colleges and universities. We must first adhere to the Marx doctrine and carry out our Party's educational policy. We must adhere to Marx and Lenin doctrine, Mao Zedong thought, Deng Xiaoping's theory, the important thought of "Three Represents", and the socialist ideology of Scientific Outlook on Development and Xi Jinping in the New Era with Chinese Characteristics to spread Marxist scientific theory. At the same time, as an extension of ideological and political theory, the practical teaching of ideological and political course in colleges and universities should always be based on the basic theory of ideological and political course. Practical teaching is not only relatively independent, but also closely related to the basic content of Ideological and political courses. Practical teaching is an important supplement to the main courses of ideological and political theory in Colleges and universities. It should not only follow the basic syllabus and teaching contents of the main courses, such as outline of modern Chinese history, ideological and moral cultivation and legal basis, introduction to basic principles of Marxism, introduction to Mao Zedong Thought and theoretical system of socialism with Chinese characteristics, but also be based on practical teaching. The specific form of learning sets its own unique teaching program.

\subsection{The Relationship Between Teacher and Student}

We should take teachers as the leading role and students as the main participants. In practice teaching, teachers play a leading role, and students are the real subject of practice teaching. The rationality of practical teaching lies in that it can fully mobilize students' enthusiasm for learning in a more flexible way as an extension of Ideological and political classroom teaching or theoretical teaching. Therefore, practical teaching should always take students as the main body of teaching, so that students can play the initiative of the main body, actively participate in practical teaching activities, confirm and sublimate the principle in practice, and innovate and develop themselves in practice. This kind of practice teaching activity with active participation as the core helps to enhance the main body's focus on learning, make it experience social life, feel and tap the charm of theory in practice, at the same time, stimulate students' interest in learning and creativity.

\subsection{The Basic Principle: The Combination of Theory and Practice}

We should take the combination of theory and practice as the basic principle and realize the goal of "unity of knowledge and practice". The purpose of practical teaching is to make students participate in practical activities, lay a solid knowledge foundation of learning subjects, strengthen students' theoretical literacy, and improve students' ability to live. Its purpose is to inject ideological and political theory into students' mind and whole life, make students "internalize in mind, externalize in action", and truly realize "unity of knowledge and practice". Education itself is not only a one-way activity, it also needs to get feedback information from the educated, so as to react on the educators and teaching activities, so that education should be constantly improved in terms of content and form, so as to ensure the effectiveness of education. Therefore, educational activities should be a two-way and always interactive process. This is also the significance of the practical teaching of Ideological and political courses in Colleges and universities. It just reasonably promotes the two-way interaction between teachers and students, teaching and learning. This is also the significance of the practical teaching of Ideological and political courses in Colleges and universities. It just reasonably promotes the two-way interaction between teachers and students, teaching and learning. In the ideological and political classroom, teachers teach students relevant theories through flexible and diverse teaching methods; in the 
practical teaching, students can better simulate or experience real life on the spot by actively participating in relevant forms of practical activities, which helps students learn to use theories to solve practical problems, and teachers can also timely understand students' learning in guiding practical activities to improve their teaching activities. On the other hand, this process contains the dual meanings of "theory" and "practice". The setting of practical teaching itself is based on Marxist theory and the practical problems of Chinese society. Therefore, students can deepen their understanding of Marxist theory and ideological and political education theory in the process of participating in practical activities. Students can more truly feel social life, thus mastering relevant knowledge and skills, and achieving the true of understanding, identification and action.

\section{The Development of Practical Teaching of Ideological and Political Theory Courses in Colleges and Universities}

Over the past 40 years of Reform and Opening Up, under the strong leadership of the Party Central Committee, We have carried out many teaching reforms in the ideological and political theory courses in Colleges and universities, including the explanation of the practical teaching of Ideological and political courses in Colleges and universities. This mainly includes: the "78 Plan" formulated after the cultural revolution; the "85 Plan" launched in the 1980s; the "98 Plan" implemented in the late 1990s; and the "05 Plan" updated and launched in the 21 st century. In other words, every change in the implementation plan of Ideological and political courses in Colleges and universities puts forward new requirements and opportunities for the development of Ideological and political courses and practical teaching in Colleges and universities.

\subsection{The "78 Plan"}

After the cultural revolution, the "78 plan" put the ideological and political courses in Colleges and universities out of order, pointing out the direction for the combination of theory and practice of Ideological and political education. After the end of the cultural revolution, under the strong advocacy of the Party Central Committee, the education sector actively carried out the work of rectifying the chaos, adhering to the working method of emancipating the mind and seeking truth from facts, and colleges and universities across the country gradually restored the course of Marxism Leninism theoretical education. At that time, the general office of the Ministry of education printed and distributed the opinions on strengthening Marxism Leninism theoretical education in Colleges and universities (the draft for consultation of the national education working conference). "In order to give full play to the role of theoretical courses in transforming students' thoughts and cultivating talents who are both red and professional", [3] the general office of the Ministry of education, in view of the problems of Marxism theoretical education, respectively, from the perspective of Marxism theory in Higher Education The status of education, the purpose and task of Marxism Leninism theory course, teaching materials, teaching methods, the construction of teachers and the leadership system are explained in detail. In the document, it is clear that Marxism Leninism theory course mainly includes four courses: "dialectical materialism and historical materialism, political economy, history of the Communist Party of China and history of the international communist movement". The document makes it clear that Marxism Leninism theory course is a compulsory course for all kinds of Socialist Colleges and universities; whether to offer Marxism Leninism theory course or not is an important sign that the new China University is different from the old China University and the socialist university is different from the capitalist University. Teachers should teach well, students should learn well and leaders should manage well. Although the document has not clearly put forward the concept of "practical teaching", it emphasizes the importance of "combining theory with practical problems", and makes clear that "on the basis of accurate teaching of basic principles, it must be closely linked with the reality of China's socialist revolution and socialist construction, and with the reality of class struggle and line struggle at home and abroad", [3] which make students distinguish theory, line and thought. In the same year, Deng Xiaoping's speech at the National Conference on education work mentioned that on the issue of the combination of education and productive labor, "the rapid development of modern economy and technology requires the rapid improvement of the quality and efficiency of education, and the continuous development of our methods in the content of the combination of education and productive labor". [4] In a word, the guidance of "78 Plan" to the ideological and political theory course mainly lies in rectifying the mistakes during the "Cultural Revolution", which points out the right direction for the later development of education.

\subsection{The "85 Plan"}

The "85 plan" highlights the teaching methods of Ideological and political courses in Colleges and universities, and clearly defines the necessity of setting up practical teaching. In the 1980s, with the continuous development of China's reform, the Party Central Committee further strengthened the disciplinary construction of Ideological and political courses in Colleges and universities. In 1985, the Party Central Committee issued the notice on reforming the teaching of Ideological and moral education and political theory in schools; in 1987, the Party Central Committee issued the decision on improving and strengthening the ideological and political work in Colleges and universities. The formulation and implementation of these two major documents have promoted the development of Ideological and political education in Colleges and universities. They not only make clear the guiding direction of Ideological and political theory course in Colleges and universities, that is, adhere to the socialist direction, but also make clear the content, form and method of improving ideological and political work in Colleges and universities, that is, carry out the education of 
Marxist theory and situation policy with a targeted aim, and actively guide the students participate in socialist practice. "Young students should learn from practice and the masses modestly, and use their knowledge to serve the masses and society. The only way for young intellectuals to grow up is to combine theory with practice, mental work with physical work, and intellectuals with the masses." [5] Only in the dual process of theoretical and practical learning can young students have a deeper understanding of "national conditions, the reality of socialist construction and reform, the ideological feelings of the people, and the belief of dedication to building a socialist motherland, and gradually become useful talents". [5] The "85 Plan" also makes clear provisions on specific matters such as the way of setting up social practice, that is, "according to the characteristics of different disciplines and different grades, different contents and methods are adopted to organize students to participate in social practice. Business practice, military training, public welfare labor and production labor should be included in the teaching plan, and students should be encouraged to use their holidays to carry out various useful social practice activities. Colleges and universities with conditions will gradually establish bases for business practice and social practice". [5]

\subsection{The "98 Plan"}

The "98 plan" has carried on the concrete explanation to the University Ideological and political course practice teaching form and so on. The reform plan of Ideological and political courses in Colleges and universities implemented at the end of $1990 \mathrm{~s}$ is formulated to adapt to the new situation and requirements of China's reform and opening up and modernization construction, especially the development of Deng Xiaoping Theory and the formation and development of the important thought of "Three Represents" have become the direct motivation to promote this reform. [6] The "98 Plan" clearly points out that we should pay attention to the reform of the teaching contents and methods of the "Two Courses", including practical teaching. We should actively adopt the methods of teaching and discussion, organizing visits and investigations, so as to integrate theory with practice, guide students to study ideological and political courses, and strive to improve the teaching effect of Ideological and political courses in Colleges and universities. The implementation of "98 Plan" has effectively promoted the diversified development of the practical teaching forms of Ideological and political courses in Colleges and universities, so that colleges and universities can fully arrange the practical teaching according to their own actual situation and characteristics.

\subsection{The "05 Plan"}

Since the new century, the " 05 Plan" as the representative of the document more systematically on the ideological and political practice teaching in Colleges and universities. In September 2004, the CPC Central Committee and the State Council jointly issued the opinions of the CPC Central
Committee and the State Council on Further Strengthening and improving the ideological and political education of college students, pointing out that "social practice is an important link in the ideological and political education of college students", and we should carry out social practice in depth. This document clearly points out that social practice "plays an irreplaceable role in promoting college students to understand the society, understand the national conditions, increase their talents, contribute to the society, exercise their perseverance, cultivate their character and enhance their sense of social responsibility. We should establish a social practice security system for college students, explore a long-term mechanism for practical education, and guide college students to go out of school, to the grass-roots level, and to the masses of workers and peasants. Colleges and universities should incorporate social practice into the overall planning and syllabus of education and teaching, stipulate class hours and credits, and provide necessary funds. We should actively explore and establish a management system that combines social practice with professional learning, service society, work study, employment, innovation and entrepreneurship, so as to enhance the effect of social practice and cultivate the labor concept and professional ethics of college students. We should seriously organize college students to participate in military and political training. We should make good use of summer and winter holidays to carry out various forms of social practice activities. We should actively organize college students to participate in social investigation, production and labor, voluntary service, public welfare activities, scientific and technological invention, work study and other social practice activities. We should pay attention to the construction of social practice base, constantly enrich the content and form of social practice, and improve the quality and effect of social practice, so that college students can receive education, grow their talents, make contributions and enhance their sense of social responsibility in social practice". [7] Then, the opinions of the China Youth Federation on Further Strengthening and improving the social practice of college students (China Youth Federation [2004] No. 3) made further supplementary explanation on the content of social practice, which made the practical teaching of Ideological and political courses in Colleges and universities have a clearer idea. In a word, the "05 Plan" formulated and implemented in the new century is a new and important plan to adapt to the continuous development of socialist modernization with Chinese characteristics in the 21 st century. It is more integrated and systematic than the previous plan, especially the content arrangement of practical teaching is more specific, which makes the practical teaching form of Ideological and political courses more mature.

\subsection{The New Plan}

Since the eighteen Party Congress, the ideological and political course in Colleges and universities is taking the opportunity of the times. Based on the "05 Plan" and guided by general secretary Xi Jinping's important speech on Strengthening Ideological and political education in Colleges 
and universities, we should continue to strengthen our reform and development and attach importance to the construction of practical teaching. Since the eighteen Party Congress, based on the strategic height of realizing the great rejuvenation of the Chinese nation, the Party Central Committee headed by general secretary $\mathrm{Xi}$ Jinping has always attached great importance to the ideological and political education in Colleges and universities, focusing on the basic issues of "cultivating what kind of people, how to train people and nurturing people". To create a "Golden Course" of Ideological and political education makes it a course that students "really like, benefit from and forget for life". At the beginning of 2018, the Ministry of Education issued the basic requirements for the teaching of Ideological and political theory in Colleges and universities in the new era. First of all, the document clearly states the important task and position of Ideological and political theory course, that is, the task of systematic Marxist theory education for college students is to consolidate the guiding position of Marxism in the field of ideology in Colleges and universities, to adhere to the important position of socialist school running direction, and to fully implement the Party's education policy, and to implement the basic task of moral education and core courses, and it is the soul course of strengthening and improving the ideological and political work in Colleges and universities and realizing the connotative development of higher education. This guidence document clarifies the specific arrangement of Ideological and political courses in Colleges and universities from 16 aspects such as guiding ideology and basic principles, which is more systematic and standardized than the previous documents. Especially the third one, "strictly implement credit", clearly stipulates that the practice teaching of Ideological and political courses in this college should be carried out, and there are independent credits. "Students can obtain corresponding credits not only by participating in the practice teaching organized by teachers, but also by submitting the application for practice results related to the study of ideological and political theory courses." Article 9 of the document "scientific application of teaching methods' explains in particular the content of practical teaching and its relationship with "theoretical teaching". "As an extension of classroom teaching, practical teaching focuses on helping students consolidate the effect of classroom learning, deepen the understanding and mastering of key and difficult problems in teaching", "to formulate practical teaching syllabus, integrate practical teaching resources, and expand practice teaching form, pay attention to the effect of practice teaching". [8]

\section{The Practical Necessity of the Development of Practical Teaching in Colleges and Universities}

\subsection{To Strengthen the Marxist Belief}

The establishment of practical teaching helps to strengthen ideological education and strengthen young students' Marxist belief from the perspective of development strategy. In his speech at the national education conference in April 1978, Deng Xiaoping mentioned that we should "improve the quality of education, improve the teaching level of science and culture, and better serve the socialist construction". "Our colleges and universities are the place to train talents for socialist construction". The quality standard of training talents lies in "making the educated develop in moral education, intellectual education and physical education, and become the educated laborers with socialist consciousness". [4] As the main channel and position of Ideological and political education for college students, the ideological and political course should take on the responsibility of systematic Marxist theory and ideological and political education for college students. The ideological and political theory course in Colleges and universities should always adhere to the Marxist position, point of view and method, combine with the reality of the modernization of socialism with Chinese characteristics, and analyze and explain the law of social development and other important issues on the basis of absorbing the essence of Chinese excellent traditional culture. As an extension of the ideological and political course in Colleges and universities, the practical teaching of Ideological and political course in Colleges and universities should adhere to the Marxist world outlook and methodology, and actively spread the ideal and belief of socialism with Chinese characteristics through various concrete forms of practical teaching. Furthermore, in the light of the world situation, national conditions and social conditions since the reform and opening up, objectively speaking, "the rapid development of modern economy and technology requires the rapid improvement of education quality and efficiency, as well as the continuous development of the contents and methods of the combination of education and productive labor", in order to avoid the situation that what students learn is not suitable for their future work, and that what they learn is not what they use and what they use is not what they learn. Therefore, the setting of practical teaching conforms to the objective requirements of our country's social development, and plays an important role in promoting the overall development of College students' learning ability and practical ability.

\subsection{An Effective Way to Realize the Objectiveness of the Ideological and Political Education}

The practical teaching is an effective way to combine the theory and practice of efficient ideological and political education. On the one hand, adhering to the connection between theory and practice is the fundamental principle and scientific method of our party and country in the process of developing socialism with Chinese characteristics. In "against the fundamentalism", Mao Zedong pointed out clearly that "the fundamentalism of Marxism should be studied, but it must be combined with the actual situation of our country". [9] In his speech at the Sixth Plenary Session of the Sixth Central Committee of the Communist Party of China, Mao Zedong stressed that we must take Marxist theory as a fundamental guide, apply it in accordance with the specific reality of the 
Chinese revolution, and closely combine the basic principles with the specific reality. In the preface and postscript of "rural investigation", Mao Zedong also put forward the slogan of "no investigation, no right to speak", "no right investigation, no right to speak" and "the only way to understand the situation is to investigate the society". [10] As the propaganda of socialism with Chinese characteristics, the cultivation of qualified builders and reliable successors of socialism with Chinese characteristics, ideological and political courses in Colleges and universities must always adhere to this basic principle. Therefore, the corresponding practice teaching of Ideological and political courses in Colleges and universities is the positive implementation of this work and basic methods. On the other hand, in the face of the new situation of social development, reform and adjustment, it is more necessary for ideological and political courses in Colleges and universities to provide students with a platform for the transformation of theoretical and practical links through practical teaching, so that they can learn theory, master skills and calmly face the challenges brought by the changing life. As General Secretary $\mathrm{Xi}$ stressed, today's China is experiencing the most extensive and profound social change in China's history, and is in the midst of a major change that hasn't happened in a century, No matter the situation of world multipolarization, economic globalization, social informatization, cultural diversity, the world is developing, but the factors of uncertainty and instability still exist, the world's economic growth is weak, trade protectionism, populism, polarization between the rich and the poor, terrorism, network security and many other problems still exist. [11] Today's college students live in the campus as students. When they leave the campus tomorrow, they will become the main force to promote the development of national production and shoulder the major mission of promoting social development and national rejuvenation. In real life, today's students and tomorrow's successors should face challenges from home and abroad, their own families and external society. Whether these college students can deal with the big and small challenges at any time will become the primary problem they will face when they go to the society in the future. The establishment of Ideological and political courses in Colleges and universities, especially the practical teaching part, is to take into account the problems and perplexities that college students may encounter, and through multi-dimensional education such as theoretical learning and practical activities, so that students can be realistic and pragmatic in the campus today, learn knowledge and skills, and establish a correct world outlook and methodology, in the face of the challenges of life, we should not be afraid of the difficulties, dare to challenge and take the time to deal with them.

\subsection{To Enhance the Effectiveness of Ideological and Political Education}

The practical teaching helps to improve the sense of acquisition of students' learning and enhance the effectiveness of Ideological and political education. Over the past 40 years of reform and opening up, our country has made tremendous changes, realizing the development of the Chinese people from "Standing Up" to "Getting Rich" to "Becoming Strong". But at the same time, it is also facing changes and adjustments in the world situation. Young students, because of their own physical and mental characteristics and the background of diversified development era, on the one hand, pay special attention to the hot spots of current affairs, social, political and economic development, and have enthusiasm to participate in social undertakings. On the other hand, due to the limited ability of their own knowledge level, coupled with the interference of complex situations such as the overlapping and collision of multiple values in the world, they are eager to seek correct solutions. Practical teaching just provides an important space platform for this. Compared with the theoretical teaching, the practical teaching is more flexible in form, which can arouse students' interest in learning, enable students to participate actively and give full play to their subjectivity. At the same time, with the development of science and technology, especially the development of artificial intelligence and other modern means, practical teaching is more intuitive, which can enable students to mobilize the whole body sensory system, so that they can experience relevant feelings and help memory. By participating in practical activities, students can get rid of some puzzles, re understand the self, society and the relationship between self and society, which is helpful to obtain relevant emotional identity. Finally, the theory of Ideological and political education can be internalized in mind and externalized in practice.

This article is the periodical achievement of the higher education teaching reform project of China Textile Industry Federation, named "Research on the Current Situation of the Examination and Assessment of the Ideological and Political Theory Course in Colleges and Universities of Science and Technology" (Project No.: 2017bkjglx272); as the phased achievement of the school level Special Teaching Research of the Ideological and Political Theory Course, named "Research on the Reform of the Examination and Assessment System of the Ideological and Political Theory Course in Colleges and Universitie (Project No.: SZZX16003).

\section{References}

[1] Zhang Guofu, "Discussion on practical teaching of Ideological and political theory course in Colleges and universities", exploration of Teaching Reform [J], 2013 (06): 56.

[2] Chen liming, "thinking about the practical teaching of Ideological and political theory course in Colleges and universities", Guiding Journal of Ideological and theoretical education [J], 2010 (02): 70.

[3] Opinions on strengthening Marxism Leninism theoretical education in Colleges and universities [OL]. Http://ahszk.ahnu.edu.cn/news_view.ASP?NewsId=182.

[4] Deng Xiaoping's speech at the National Education Conference [OL]. Http://www.jyb.cn/zyk/jyzcfg/200602/t20060227_html. 
[5] Decision of the CPC Central Committee on improving and strengthening ideological and political work in Colleges and universities [OL]. Https://baike.baidu.com/item/decision of the CPC Central Committee on improving and strengthening ideological and political work in Colleges and universities / 5590884 ? Fr $=$ Aladdin .

[6] Ding Guohao, "basic experience and trend of Ideological and political teaching method reform in Colleges and universities since the reform and opening up", frontier [J], 2013 (1): 146.

[7] Opinions of the CPC Central Committee and the State Council on Further Strengthening and improving ideological and political education of college students [OL]. Http:/graduate.cqnu.edu.cn/students/sizheng/201205/381.htm 1.
[8] Circular of the Ministry of education on printing and distributing the basic requirements for the teaching of Ideological and political theory courses in Colleges and universities in the new era [OL]. Http://yjsb.tjpu.edu.cn/2019/0417/c2875a43177/page.htm.

[9] Against essentialism, selected works of Mao Zedong (Volume 1) [M]. Beijing: People's publishing house, 1991, p. 111-112.

[10] Preface and postscript of "rural investigation", selected works of Mao Zedong (Volume 3) [M]. Beijing: People's publishing house, 1991, p. 789.

[11] Xi Jinping's learning outline of socialism with Chinese characteristics in the new era [M]. Beijing: learning press, 2019, p. 2 . 